8. Elizaveta Kruglikova. (2019). International Monotype Festival website. Retrieved from http://www.shedevr.com.ua/?author=k/kruglikova [in Russian].
9. Tarkhanov
Mykhailo
Mykhailovych.
(2019).
Site
Retrieved from

\begin{abstract}
Art
\end{abstract}
investment. https://artinvestment.ru/auctions/1006/biography.html [in Russian].

Стаття надійшла до редакції 03.12.2019 p. Прийнято до публікації 26.12.2019 p.

UDC 738.1:738.3(477)"19"

\author{
Shkolna Olga \\ the doctor of Art criticism, the Professor, \\ the Professor of the Boris Grinchenko Kyiv University \\ ORCID 0000-0002-7245-6010 \\ dushaorchidei@ukr.net
}

\title{
PRODUCTION OF HIGH FAIENCE AT THE PACYKYVSKA FAIENCE FACTORY DURING 1912-1939
}

The purpose of the article. The goal is to outline the main creative achievements of the Patsykyvska faience factory. The methodology consists of the totality of the application of the historical-chronological approach, historicalcultural, axiological and art history methods, which allow you to review previously known information regarding the mentioned production. The scientific novelty consists in the addition and refinement of information regarding the activities of the outlined enterprise and the addition of newly revealed data regarding the owners of the Patsykyvska faience factory. Conclusions. Based on the latest information regarding the formation, development, and activities of the Patsykyvska faience factory, it was possible to verify previously known information on the start of production, which, judging by archival sources, has been operating since 1912. Local history studies of the village of Pidlissya, which, according to the new administrative-territorial division, covers Patsykyv's former territories in the vast modern Ivano-Frankivsk region made it possible to supplement the information on the stages of reconstruction and modernization of the enterprise, previously unknown to the general public related to the wartime of 1914-1918. The identification of the latest archival data, photographs, and sights from various state and private collections of Ukraine and Poland over the past years made it possible to clarify the names of the production of different periods, which was originally called the Erst Galician Factory of Faience and Terracotta in Patsykyv near Stanislavov, and in the interwar period - Polish factory of faience «Patsykyv» near Stanislaviv.

Key words: Patsykyvska faience factory, Ukraine, XX century, owners, enterprise infrastructure.

\begin{abstract}
Школьна Ольга Володимирівна, доктор мистецтвознавства, профресор Київського університету імені Бориса Грінченка

Продукування високого фаянсу на Пациківській фаянсовій фабриці впродовж 1912-1939 рр.

Мета - розглянути особливості фабрикації скульптури і посудних виробів на Пациківській фаянсовій фрабриці впродовж 1912-1939/1941 рр. Методологія дослідження складається з сукупності застосування історико-хронологічного підходу, історико-культурного, аксіологічного та мистецтвознавчого методів, які дозволяють переглянути раніше відому інформацію щодо згаданого виробництва. Наукова новизна полягає у доповненні й уточненні відомостей щодо діяльності Пациківської фаянсової фабрики у період з 1912 по 1939/1941рр. Висновки. Виходячи з останніх відомостей відносно становлення, розвитку і функціонування Пациківської фраянсової фабрики, вдалося здійснити верифікацію раніше відомої інформації щодо початку діяльності виробництва, що, судячи з архівних джерел, діяла з 1912 р. Краєзнавчі дослідження села Підлісся, яке за новим адміністративнотериторіальним поділом охоплює колишні території Пацикова на теренах сучасної Івано-Франківщини, дозволили доповнити відомості про етапи реконструкції та модернізації підприємства, раніше невідомі широкому загалу, пов'язані із воєнним часом 1914-1918 рр. Виявлення новітніх архівних даних, світлин і пам'яток з різних державних і приватних збірок України та Польщі впродовж останніх років, уможливили уточнення назв виробництва різних періодів, що початково іменувалося Перша Галицька фабрика фаянсу і теракоти в Пацикові біля Станіславова, а у міжвоєнний час - Польська фрабрика фаянсу «Пациків» біля Станіславова.
\end{abstract}

Ключові слова: Пациківська фраянсова фрабрика, Україна, XX століття, власники, інфраструктура підприємства.

Школьная Ольга Владимировна, доктор искусствоведения, профрессор Киевского университета имени Бориса Гринченко

Продуцирование высокого фаянса на Пациковской фаянсовой фабрике в течение 1912-1939 гг.

Цель - очертить основные творческие достижения Пациковской фаянсовой фабрики. Методология исследования состоит из совокупности применения историко-хронологического подхода, историко-культурного, аксиологического и искусствоведческого методов, которые позволяют пересмотреть ранее известную информацию относительно упомянутого производства. Научная новизна заключается в дополнении и уточнении сведений касательно функционирования очерченного предприятия и прибавления нововыявленных данных относительно владельцев Пациковской фраянсовой фабрики. Выводы. Исходя из последних сведений относительно становления, развития и деятельности Пациковской фаянсовой фабрики, удалось осуществить верификацию ранее известной информации относительно начала деятельности производства, что, судя по архивным источни-

(C) Shkolna O., 2020 
кам, функционировала с 1912 г. Краеведческие исследования села Пидлисся, которое по новому административно-территориальному делению охватывает бывшие территории Пацикова на просторах современной ИваноФранковщины, позволили дополнить сведения об этапах реконструкции и модернизации предприятия, ранее неизвестные широкой общественности, связанные с военным временем 1914-1918 гг. Выявление новейших архивных данных, фотографий и достопримечательностей из разных государственных и частных собраний Украины и Польши в течении последних лет, осуществили уточнение названий производства разных периодов, что изначально именовалось Первая Галицкая фабрика фраянса и терракоты в Пацикове около Станиславова, а в межвоенное время - Польская фабрика фаянса «Пациков» около Станиславова. предприятия.

Ключевые слова: Пациковская фраянсовая фрабрика, Украина, XX век, владельцы, инфраструктура

Постановка проблеми. Сьогодні продукція Пациківської фаянсової фабрики (сучасного Тисменицького району на Івано-Франківщині), яка впродовж 1910-х - 1930-х рр. була надзвичайно популярною в Австро-Угорській імперії, Німеччині, етнічних Україні та Польщі, вітчизняним мистецтвознавцям і колекціонерам майже невідома, хоча на ній працювали кращі скульптори малих форм того часу, творчість яких досі не є в повній мірі осмисленою.

Зважаючи на те, що на даному виробництві було утворено своєрідну художню лабораторію для розробки творчих взірців високого фраянсу і фарфору, Пациків у добу модерну - ар деко відіграв для теренів Східної Галичини подібну роль до Імператорського фрарфорового заводу у СанктПетербурзі, де також працювали талановиті художники з України (Аліса Брускетті-Мітрохіна, сестри Олена та Наталя Данько, Єлизавета Трипільська).

Натомість діяльність низки визначних скульпторів епохи, які розробляли свої творчі роботи на базі Пациківської фаянсової фабрики, досі повноцінно не введена до наукового обігу. Так, проекти масових виробів, крім віртуозних пластиків Станіслава Еміля Чапека (нар. 1874 - ? рр.), Антона Попеля (1859 або 1865-1910 рр.) та Люни Амалії Дрекслер (1882 - 1933 рр.), виконували Тадеуш Блотницький (1858-1928 рр.), Юзеф Хмелінський (1862-1941рр.), Казимир Клакович (бл. 1874 - після 1939 рр.), Роберт Людвиг (бл. 1880 - після 1939 рр.), Йосип Левицький (1880-1964рр.), Антон Слугоцький (1881-1939рр.), Вільгельм Томаш (1893-1964рр.) та ціла плеяда інших майстрів, більшість з яких становили львів'яни.

Частина з них пройшла вишкіл також у кращих скульптурних майстернях мистецьких академій Відня, Кракова (зокрема, А. Попель, Т. Блотницький, С. Чапек, В. Томаш), де означені митці й отримали перший досвід роботи з «білим золотом». Це накладало певний відбиток елітарної культури на їх твори, позначені присмаком великосвітського безтурботного життя (яскравим прикладом є парна статуетка С. Чапека «Канкан», присвячена танцю, що був модним на початку XX ст. у кафешантанах).

Деякі митці Пацикова, як, приміром, Л. Дрекслер, від суто імпресіоністичного ліплення в дусі Бурделя (в майстерні якого вона вчилася в Парижі перед стажуванням у Римі та Мюнхені), поступово переходили до S-подібних модерних силуетів. При цьому поліхромній скульптурі малих форм, що ліпилась з натури, надавався «танцювальний характер» (С. Чапек), що було тенденцією, характерною для доби ар деко. 3 відстані часу, за можливості осягнути весь напрацьований означеними майстрами доробок на Пациківській фраянсовій фрабриці, їх творчі здобутки з сюжетами зачитаних дам у кринолінах, соціально значущих дам-суфражисток (поборниць за жіночі права) з цигарками, закоханих пар тощо можна порівнювати хіба що з елітарним фарфором і фраянсом Відня, Майсену, Берліну, Копенгагену чи Севру [5]. Адже у творчості митців означеної плеяди виразно проступає «духовноідеалістичне начало» на тлі пластичної виразності фрорм і декоративного вирішення поверхонь виробів.

Аналіз останніх досліджень і публікацій. 3-поміж останніх розвідок, присвячених спадщині Пациківської фаянсової фрабрики, варто назвати кілька вітчизняних публікацій. Перша, Р. Чорненького та П. Гаврилишина під назвою «Статуетки з Пацикова. У ній наводяться імена «артистів» (цебто представників творчої частини) виробництва, деякі з яких раніше були невідомі. Також в означеній статті здійснено розгляд облаштування підприємства, чим для нас дана робота є надзвичайно цінною [4].

Істотний її мінус - брак будь-яких посилань, які б уможливили верифрікацію наведених даних. Однак, існує ймовірність, що матеріали отримані автором дослідження від спадкоємців колишніх власників фабрики. Адже в праці також суттєво розширено інформацію про рід Левицьких, котрий володів цим бізнесом протягом історії існування фабрики. За даними відомого львівського архівіста $\mathrm{B}$. Александровича, попередньо було відомо про наявність такого родинного архіву в польського спадкоємця, архітектора Якуба Левицького, який, на жаль, раніше не був готовий нею поділитися.

Другою розвідкою, яка останнім часом збагатила інтернет-простір, є також анонімна стаття під назвою «Фабрика фаянсової скульптури у Пацикові біля Станіславова: втрачена історія. Фото», оприлюднена на сайті новин kurs.if.ua 01.12.2016 р. Її сильною стороною $є$ наведення архівних фото зі збірки мандрівника і колекціонера історичних фото, фрранківця Роберта Еріка, що виклав в інтернетмережі альбом світлин з Пацикова. Слабкою - помилка у даті заснування підприємства, що безпідставно позначена 1902 роком [3].

У третій анонімній статті під назвою «Сто років тому у прикарпатському селі діяла знаменита фраянсова фабрика», оприлюдненій на сайті blitz.if.ua, йдеться про першу назву «Галицька фрабрика 
теракоти і фраянсу», яку пізніше було перероблено у «Перший Галицький завод фраянсу і теракоти». Тут само сказано й про те, що початково за власника Олександра Левицького, на виробництві тут працювали австрійці, чехи та поляки [2]. (Принагідно варто зауважити, що в даній розвідці прізвище власника було ототожнене з іншим фабрикантом початку XX століття - Левінським).

Загалом слід зазначити, що всі ці публікації вийшли друком після низки статей доктора мистецтвознавства О. Школьної про означене підприємство, що базувалися на матеріалах польських та українських колекцій, а також розвідки Б. Костух, яка спиралася на розробки попередниці М. Єзевської та артефакти з Краківського національного музею [5; 6; 7]. Однак посилань на ці першоджерела, як і на інші публікації, автори згаданих прикарпатських новин не наводять.

Мета статті - розглянути специфіку фрабрикації виробів Пациківської фаянсової фрабрики 1910x - 1930-х рр. з урахуванням нововиявлених даних і проаналізувати мистецькі досягнення підприємства впродовж окресленого періоду.

Новизна роботи полягає у зведенні варіантів назв Пациківської фраянсової фрабрики різних років; систематизації інформації про специфіку виробничих процесів на підприємстві; уточненні даних про власників, керівників виробництва і повного переліку імен майстрів художньої частини; наведенні переліку асортименту продукції.

Виклад основного матеріалу дослідження з обґрунтуванням отриманих наукових результатів. Виходячи з сукупності нововиявленої та раніше оприлюдненої інформації щодо означеного підприємства, слід зазначити, що зведені корпуси виробництва в Пацикові були між 1908 і 1910 роками, натомість урухомлена фрабрика лишень на 1912 рік [5]. Відповідно, виготовлення продукції стало можливим лише з цього часу.

Засновником і власником за документами значився підполковник артилерії, член ТорговоПромислової палати Олександр Левицький (11.07.1877 - 11.12.1935), син відомого власника Малярні Казимира Левицького у Львові, що ще 1845 р. відкрив у місті Лева магазин фрарфору, фаянсу і скла [5, 200]. Перший володів також підприємством з видобування мінеральної води «Dewajtis» у Пацикові, маєтністю у Львові, де він і мешкав, та 3500 моргами орної землі на Прикарпатті [4]. Рання назва виробництва звучала як «Erste Galizishe Terrakota und Fayence Fabrik» [5]. Підприємство протягом свого існування кілька разів перепрофільовувалося, що, відповідно, і відображалося у назві.

Враховуючи, що устатковане виробництво було на 1912 рік, а вже 1914 почалася Перша світова війна, більшою мірою під час військових дій до 1918 року, а також від 1918 до 1920 рр. воно не працювало. Будівля фрабрики була зруйнована, тому надалі її відбудували [4].

У перший період діяльності продукція виготовлялася типово західноєвропейська, на фабриці працювали відомі скульптори того часу. Крім того, фабрика випускала дешеву посудну білизну, що декорувалася у Малярні Казимира Левицького у Львові, що після смерті батька перейшла у спадок Олександру та його брату Якову (1875-1937рр.) [5, 200]. Судячи зі світлин, які нині оприлюднені Робертом Еріком, це були здебільшого вази для квітів, декоративні вазочки невеликих розмірів, глечики, чашки, піали, салатники, тарілки, попільнички, вазони [2], а також жардиньєрки, настільні лампи, корпуси для годинників, скульптура [5, 200-206].

Першим управителем (з перервою на період Першої світової війни) від 1912 до 1924 р. був скульптор Станіслав Чапек, що навчався у Львові та Відні, автор ранніх творів фабрики. Проекти масових виробів на підприємстві розробляли львівські скульптори Тадеуш Блотницький, Люна Амалія Дрекслер, Казимир Клакович, Йосип Левицький, Роберт Людвіг, Антон Попель, Владислав Поубернський, Антон Слугоцький, Юзеф Хмелінський, дочка останнього Ірена Хмелінська. При цьому в окремих першоджерелах згадувалися імена виконавців Вацлава Шимановського, Мечислава Зав(i)єйського, Словацького, Асника, Уэйського, Хмелевського. Окремі роботи закуповувались у випускника Краківської школи промислу артистичного Владислава Адамека й інших знаних майстрів школи Шафрана. Упродовж 1920-х - 1939 рр. у Пацикові випускали й скульптури за творами учнів Стахури - Казимира Даско і Гоголя, проектами Станіслава Урсин-Русицького, моделяра Владислава Габковського [5, 201].

Р. Чорненький зазначає також скульптора Владислава Грубельського і працівника «Артистичного відділу», який діяв з 1920 по 1932 р., Йозефа Когутяка. 3-поміж працівників інших структурних підрозділів за його даними фрігурували майстри Павло Середюк, Юрій Желюк, Петро Катрич, Дмитро Кіндрацький, Олександр Дичаківський, частина з яких була місцевими мешканцями Пацикова. Управителем фабрики після С. Чапека значились бельгійський інженер Файтсі (1924р.), надалі різьбяр і керамік Вільгельм Томаш, за проектами якого випускали більшість скульптури підприємства 1920-х рр. [5]. Потому їх змінив вихрещений єврей Туховський (Тух), одружений на українці Ользі Ковальській [4].

На 1921 р. загальна кількість робітників розраховувала на 200 осіб, хоча по фракту було задіяно лише 50. 1925 р. більшість некваліфрікованих українських працівників фабрики замінили на польських. У період найбільшого розквіту виробництва тут працювало 350 осіб. На рік у Пацикові виготовляли до 50 тис. одиниць готової продукції.

1932 р. підприємство через фрінансові труднощі тимчасово не працювало. 1935 р. помер перший власник Олександр. Відтоді фабрикою володів його син Олександр Юрій Левицький, що керував підприємством до початку Другої світової війни, коли діяльність останнього була припинена. 3 націо- 
налізацією виробництва, 1944 р. тут розмістили кахельний цех Станіславського цегельного заводу, на якому робили кахлі до п'єців (ансамблів пічної кераміки та груб) [4].

Розташовувалося підприємство неподалік від зручних транспортних шляхів, поруч із дорогою Загвіздя-Пациків (нині ця місцевість відноситься до Загвіздя). Місце для побудови фрабрики було вибране у зв'язку із наявністю поруч, неподалік від річки Бистриці Солотвинської, родовища глини, що була придатна для виготовлення фраянсових виробів. Ї̈̈ застосовували разом із крейдою та піском. Специфріка місцевої маси після додавання німецького каоліну полягала у її особливих пластичних властивостях. По висушуванні вона давала рівну поверхню без пор і розтріскувань, гарно трималася купи. Вироби легко піддавались формуванню і пластичному моделюванню, зберігали гладкість фрактури, придатної для нанесення малюнку керамічними й емалевими фрарбами [4].

Виробничий комплекс складали досить просторі цегляні корпуси, деякі з яких були двоповерховими, під шифером та ґонтою, облаштовані протипожежними східцями. Між п'ятьмома мурованими будівлями розташовувся колодязь. Перший корпус $(16,2 \times 11,5$ м) був випалювально-виробничим. На його нижньому поверсі розміщувалося дві одноповерхові печі німецького типу для випалювання теракоти та фраянсу системи «Schulce», об'ємом 20 куб. м. Муровані з шамотної цегли, всередині вони були вкриті вогнестійкою глиною, завершувалися димарем заввишки 12,4 м. На другому поверсі цієї споруди була облаштована майстерня з випалу посуду та скульптури [4].

Другий корпус містив сушильний відділ й емальєрну майстерню. У третьому на першому поверсі знаходилася майстерня з декорування та ретушування фраянсу, а також склад готової продукції, на другому - хімічна лабораторія, майстерня з малювання та ретушування теракоти, канцелярія. В підвальному приміщенні цієї будівлі було встановлено дизельний двигун. У четвертій споруді розміщувався художній відділ з токарнею, сушильнею та модельною майстернею. В підвалі корпусу знаходилися майстерня очищення глини та майстерня емалі. П'ята споруда містила чотири печі по 2,5 на 2,5 м, заввишки 3,25 м, об'ємом 2 куб. м. На її другому поверсі розміщувалася сушарня, де вироби висушували перед обпалом. Додаткові господарчі споруди розташовувалися ближче до огорожі. Там у кількох будинках зберігалося паливо, інгредієнти для виготовлення фраянсу та фрарфору, знаходився відділ сортування та пакування, а також гараж [4].

Малювальну майстерню було устатковано ексгаузером (очищувач повітря), що працював від дизельного двигуна «Dejmlev» в три кінських сили. Для розпилення фрарби аерографом застосовували бляшані столи в скляних будках. Дизельний двигун фрірми «Diesel» у 12 кінських сил урухомлював шість токарних верстатів. Вони також поєднувалися трансмісією із водним двигуном, який заміняв дизельний у разі його несправності. Електрику для власних потреб продукував двигун «Brown-Boberi». Від 1928 р. на підприємстві було облаштовано новий резервуар для збору води і каналізацію, труби 3 якої вели до річки Бистриці Солотвинської, куди скидалися стоки [4].

Хімічні сполуки для керамічної фарби й емалі завозилися з закордону. Деякі домішки додавали й до основного складу керамічної маси для кращого розмелювання, аби отримати шлікер. Відливання, формування, виточування скульптури виконувалося за допомогою гіпсових фрорм, які виробляли на місці з алебастру. Після першого утильного випалу заготовки покривали за допомогою аерографу із тисненим повітрям криттям або ручним розписом. Після вкриття емаллю обпалювали вдруге. Паливом слугували дерево, вугілля або високоякісний кокс за температури $1150-1250{ }^{\circ} \mathrm{C}(3$. Чорненький помилково зазначав від 150 до $250{ }^{\circ} \mathrm{C}$ ) [4], що дозволяло випалювати як високоякісні майоліку та фаянс, так і низькотемпературний фарфор (Рис. 2).

Продукцію продавали спочатку по теренах Австро-Угорської імперії та Німеччини, а у період між Першою та Другою світовими війнами експортували, насамперед, до країн Західної Європи. Крім того, на Маріацькій площі у будинку №5 у Львові (нині пл. Адама Міцкевича) знаходився фрірмовий магазин підприємства. Також продукція Пацикова до 1938 р. [3] збувалася і в торговому павільйоні на виставці «Східні торги» (Рис. 1), що на той час був найбільшим серед виставкових заходів Галичини [4]. Від 1913 р асортимент фабрики був відомим й у Києві, де конкурував з відомими європейськими виробництвами і завоював золоту медаль, та Ляйпцігу [5, 199; 2]. 


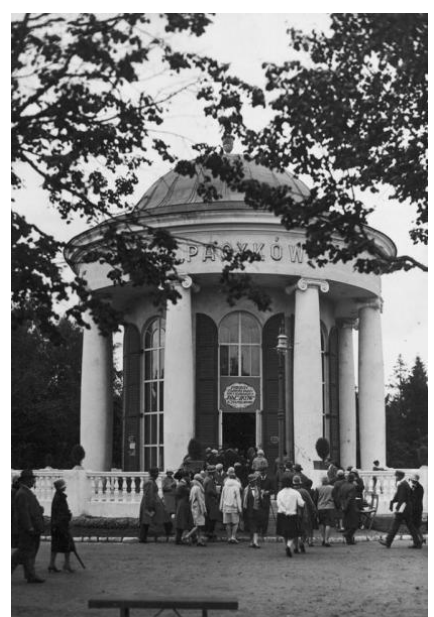

Рис. 1.Павільйон у Львов. Фото 1938 р.

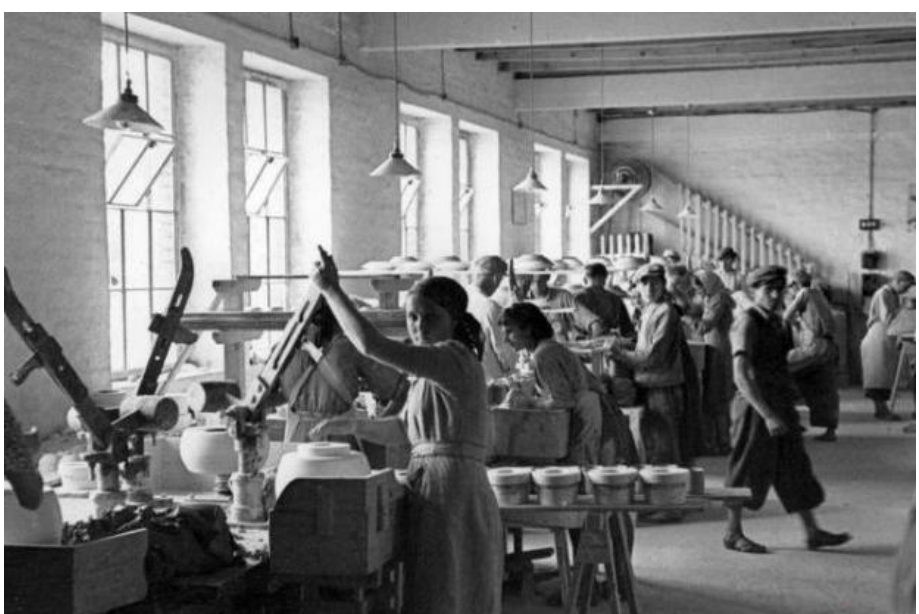

Pис. 2. Виробництво Пациківської фаянсової фабрики.

Судячи зі світлин, які оприлюднені впродовж останнього року, підприємство працювало й за німців, які цікавилися його продукцією, й, імовірніше за все, у цей період частина творів потрапляла до етнічної Німеччини [3]. Відповідно, конкурувала з тонкокерамічною продукцією провідних європейських брендів, насамперед, Майсену та Берліну.

Найбільш виразними з виробів Пацикова були образи панн за вільмин проводженням часу («Канкан» А. Попеля) (Рис. 3), феміністок, суфражисток, парижанок у широких капелюхах і панчохах (автор Люна Дрекслер) (Рис. 4), вирішені в стилістиці модерну та раннього ар деко, що увиразнили «обличчя» пациківської тонкої кераміки з-поміж інших виробництв «білого золота» Європи початку XX століття. По суті, це був високий фраянс, кращі зразки якого дорівнювали елітарній продукції Майсена, Берліна, Аугартена, Севра. Судячи з деяких клейм, підприємство певний період часу мало назву «Фабрика польських фаянсів», а сучасники іменували її «Фабрикою модних фраянсів». Високий художній рівень виробів став приводом для закупівлі продукції музеями витончених мистецтв у Лодзі, Варшаві, Вроцлаві, Битомі, Львові, Острозі [5, 199-206].

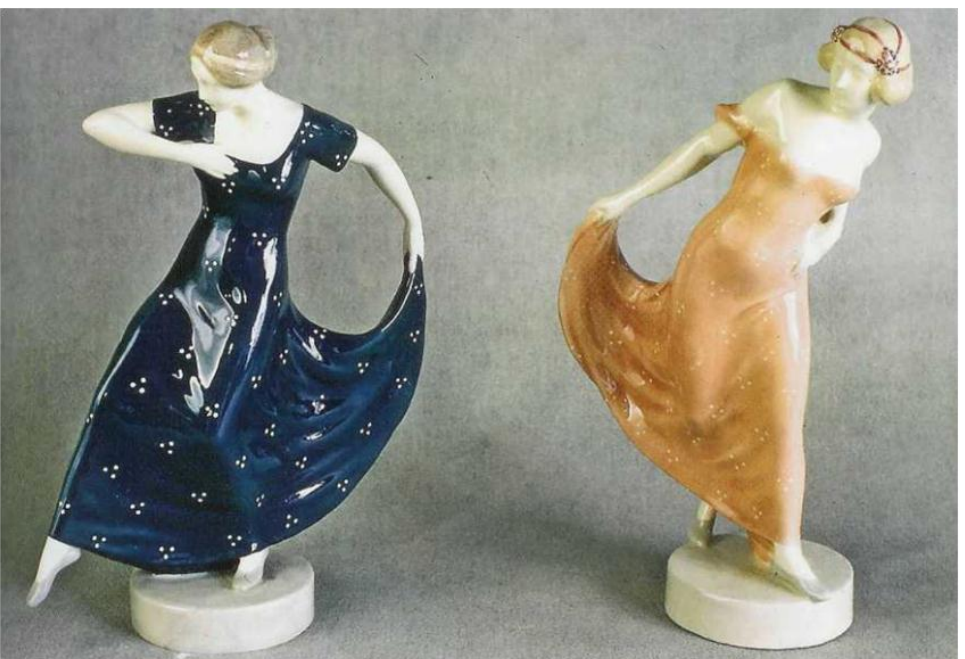

Рuс. 3. Попель А. Парна скульптура (сюїта) "Дівчини в танку». Близько 1912-1914 рр. Пациківська фаянсова фабрика. Збірка львівського Музею етнографії та художнього промислу.

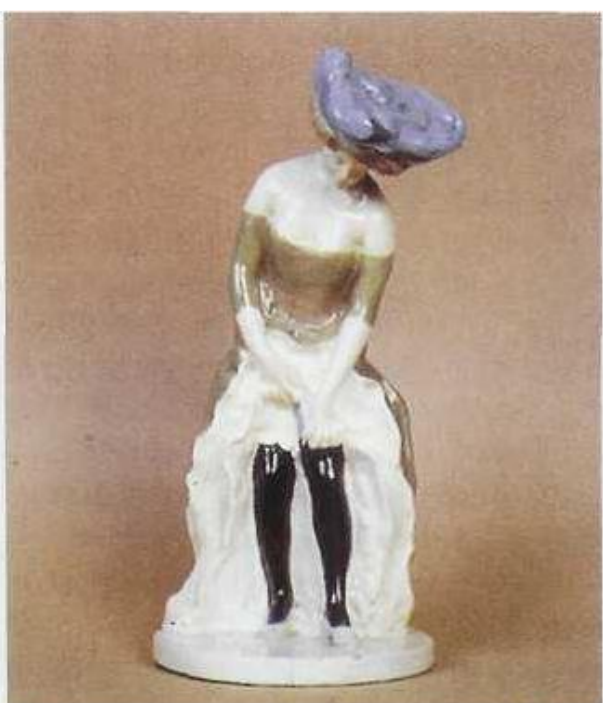

Рис. 4. Дрекслер Л. «Дама, що надягає панчохи». Близько 1912-1914 pр. Пациківська фаянсова фабрика. Збірка Музею мистецтв у Лодзі (Польща).

Висновки. Отже, розглянувши етапи й особливості життєдіяльності Пациківської фраянсової фабрики, можна навести кілька назв, які передували одна одній, або й використовувалися в один час. Початково підприємство діяло як «Erste Galizishe Terrakota und Fayence Fabrik» (за документами) або «Pierwsza galicyjska fabr. art. fajansow i terracot<...> Pacykow» (за клеймами), в експортних зразках додатково ставився регіон виготовлення «Galicie» (1912-1914 pp., 1921-1929 рр.). Після Першої світової 
війни воно було переіменоване у «Польську фабрику фаянсів "Пациків"» або «Фабрику польських фаянсів "Пациків"», а сучасники іменували ії «Фабрикою модних фраянсів» (1930-1932 рр., 19331939/1944рр.). Специфіка виробничих процесів на підприємстві була пов'язана із використанням як місцевих, так і німецьких глин а також кількох печей німецького типу, котрі закуповувались власниками Олександром та його сином Олександром Юрієм Левицькими. При цьому цикл фабрикації розроблявся провідними художниками-скульпторами та технологами, що пройшли вишкіл як в Україні, так і за кордоном: С. Чапеком, бельгійським інженером Файтсі (1924р.), надалі різьбярем і кераміком Вільгельмом Томашем, євреєм Туховським (Тухом). Доповнений перелік імен майстрів художньої частини наразі виглядає наступним чином: львівські скульптори Тадеуш Блотницький, Люна Амалія Дрекслер, Казимир Клакович, Йосип Левицький, Роберт Людвіг, Антон Попель, Владислав Поубернський, Антон Слугоцький, Юзеф Хмелінський, Ірена Хмелінська, також у виробництво йшли окремі проекти моделяра Владислава Габковського. Виконавцями працювали Вацлав Шимановський, Мечислав Зав(i)єйський, Словацький, Асник, Уэйський, Хмелевський. Окремі роботи закуповувались у випускника Краківської школи промислу артистичного Владислава Адамека й інших знаних майстрів школи Шафрана, учнів Стахури Казимира Даско і Гоголя. Крім перелічених, відомі імена скульптора Владислава Грубельського і майстрів Йозефра Когутяка, Павла Середюка, Юрія Желюка, Петра Катрича, Дмитра Кіндрацького, Олександра Дичаківського, частина з яких була з Пацикова.

Асортимент відомих творів складався з ваз для квітів, вазочок невеликих розмірів, глечиків, чашок, піал, салатників, тарілок, попільничок, вазонів, жардиньєрок, настільних ламп, корпусів для годинників, скульптури. Успіх продукції варто пов'язувати із серією фраянсових фрігурок С. Чапека, Л. Дреклер та Ю. Хмелінського, що кореспондували із творчістю провідних майстрів югендстилю - ар деко Теодора Хентшеля й Альфреда Кьоніга.

\section{תimepamypa}

1. Прикарпатське село Пациків століття тому славилося своїм фраянсом. ФОТО (Прикарпатський колекціонер історичних світлин Роберт Ерік опублікував альбом із добіркою світлин села Пациків. 12.01.2016). URL: http://vikna.if.ua/news/category/7/2016/12/01/64396/view. (Дата звернення: 25.08.2019р.)

2. Сто років тому у прикарпатському селі діяла знаменита фаянсова фрабрика. URL: http://www.blitz.if.ua/news/sto-rokiv-tomu-u-prykarpaskomu-seli-diyala-znamenyta-fayansova-fabryka.html. Дата звернення: $25.08 .2019 \mathrm{p}$.

3. Фабрика фаянсової скульптури у Пацикові біля Станіславова: втрачена історія. ФOTO. URL: https://kurs.if.ua/news/fayansova_fabryka_u_patsykovi_bilya_stanislavova_vtrachena_istoriya_foto_47370.html. Дата звернення: $26.08 .2019 \mathrm{p}$.

4. Чорненький Р., Гаврилишин П. Статуетки з Пацикова (15.10.2018). URL: http://gk-press.ff.ua/statuetky-zpatsykova/?fbclid=IwAR1WkdMyAUuVfxHTLNaRUSJjM8v7ZEr7LkYsdMmJYd-zuB0XjLfglw2CHUU. Дата звернення: 26.08.2019 p.

5. Школьна О. Пациків, Пациківска фраянсова фабрика (Пациківська фабрика фаянсових виробів Олександра Левинського). Фарфор-фаянс України. Історія виробництв, реєстр імен провідних майстрів галузі. Книга друга, частина перша. Київ: День печати, 2013. С. 198-206.

6. Jeżewska M. Ceramika polska XX wieku. Wrocław, 1992. S. 78-79.

7. Kostuch B. Pacyków. Ceramika w pierwszej polowy XX wieku. Katalogi zbiorów Muzeum narodowego w Krakowie. Kraków. 2001. №10. S. 195-210: il.

\section{References}

1. The Prykarpattya village of Pacykivwas famous for the glazed pottery. PHOTO (12.01.2016, The Prykarpattya collector of historical photos Robert Erik published an album with the selection of photos of the village of Pacykiv). 12.01.2016). URL: http://vikna.if.ua/news/category/7/2016/12/01/64396/view. Date of access: in 25.08 .2019 [in Ukrainian].

2. One hundred years ago the famous made of delftware factory operated in the Prykarpattya village. URL: http://www.blitz.if.ua/news/sto-rokiv-tomu-u-prykarpaskomu-seli-diyala-znamenyta-fayansova-fabryka.html. Date of access: in 25.08.2019 [in Ukrainian].

3. Factory of the made of delft ware sculpture in of Pacykov of near of Stanislaviv: the lost history. PHOTO. URL: https://kurs.if.ua/news/fayansova_fabryka_u_patsykovi_bilya_stanislavova_vtrachena_istoriya_foto_47370.html. Date of access: in 26.08 .2019 [in Ukrainian].

4. Chornen'kyj R., Gavrilishin P. (15.10.2018) Statuettes from Patsykov. URL: http://gk-press.if.ua/statuetky-zpatsykova/?fbclid=IwAR1WkdMyAUuVfxHTLNaRUSJjM8v7ZEr7LkYsdMmJYd-zuBOXjLfglw2CHUU. Date of access: in 26.08.2019 [in Ukrainian].

5. Shkol'na O. (2013). Patsykiv, Patsykivsky Faience Factory (Patsykivsky Factory of Faience Products of Alexander Levinsky). Shkol'na O. Porcelain-ware of Ukraine. Production history, register of names of leading masters of the industry. Book Two, Part One. Kyiv: Press Day. P. 198-206 [in Ukrainian].

6. Jeżewska M. (1992). Polish Ceramics of XX of age. Wroclaw. P. 78-79. [in Polish].

7. Kostuch B. (2001)i.Pacyków. Ceramics in first field XX of age // Catalogues of collections of national Museum in Krakowie. Kraków. №10. P. 195-210: il. [in Polish]. 